\title{
Investigating Participation Motives of Saudi University Students towards Physical Activity at Different Educational Levels
}

\author{
Varghese C. Antony* and Rakesh Tomar \\ Physical Education Department, King Fahd University of Petroleum and Minerals, Saudi Arabia; \\ vcantony@kfupm.edu.sa,varghesecat@gmail.com
}

\begin{abstract}
Background/Objectives: Motivation is a complex phenomenon that driven from the 'inside' by some needs, impulses, desires, wishes, or motives, and directed towards achieving a goal that from the outside functions as a stimulus for behavior. The objective of the study was to investigate participation motives of Saudi university students towards physical activity at different educational levels. Method: The participants were undergraduate students ( $\mathrm{n}=1039)$, mean age $20.60 \pm 1.679$ yrs. On the basis of educational level five categories were formed as orientation $(n=352)$, freshmen $(n=293)$, sophomore $(n=191)$, junior $(n=93)$, and senior $(n=110)$. Motivation for Physical Activities Measure-Revised was administered to measure participation motives. Rank order applied for the most and least important reasons for participation towards physical activity and sports. Findings: University students' rated the most important reasons for participation towards physical activity and sports as fitness and then appearance factors, which are explained by extrinsic motivation. The least important reason for participation motivation reported was social factors. It was observed that students always take time to find friends. It might be due to this choice of friendship that students consider as the main reason to participate in physical activity Ryckman and Hamel. ANOVA showed significant differences among educational levels on competence factor 3.419, $p=.009$; social factor 9.746, $p=.001$. Students tend to improve their competence, enjoyment or interest through physical activity and sports to optimize their physical well-being with progression of educational levels. Application/ Improvement: To impart the knowledge of fitness and health benefits, mentors and counselors should help and motivate students to take up the physical activities seriously. The infrastructural facilities for physical activities are not optimizing it to their advantage. To optimize the social experience of students there is a need for strategies to reduce the gap in socialization among students.
\end{abstract}

Keywords: Educational Level, Fitness, Motivation, Participation, Physical Activity

\section{Introduction}

Motivation is understood as an impetus for exercising and it is a complex phenomenon that is unacceptable to simply include under a single model ${ }^{1}$. Sports are considered one specific form of physical activity that contributes to children's and adolescents' overall engagement in moderate to vigorous physical activity ${ }^{2}$. When compared to other forms of physical activities, sports participation typically involves physical exertion and skill development, and the competition of individuals or teams against one another ${ }^{3}$. Participation in sports and physical activities has been proved to have great positive effect on human body, but not all positive effects are strong enough to make people participate in the sports. It is a common belief that motivation plays a major role in participation in physical activity ${ }^{4}$.

${ }^{*}$ Author for correspondence 
Weiss and Petlickhoff ${ }^{5}$ noted that key reason to participate in physical activities as fitness, competence, affiliation and fun. Some studies demonstrated that people have different achievement goals with respect to sports participation and it is logical to recommend that their achievement is a fundamental of enjoyment ${ }^{6,7}$.

Motives are very important components of physical activity participation. Physical activity has both preventive and curative effects ${ }^{8,9}$. According to Sport and Health $^{10}$ in 2005 more than thirty five million people succumbed to chronic diseases, which are preventable through participation in physical activities. Many studies have indicated that young people are not physically active as they need to be to enjoy the health benefits of physical activity $^{11-14}$.

The motivational theories propose a mechanistic nature of viewing man as passive and driven by psychological causes. But the cognitive theories viewing, man as actively processing and interpreting the achievement perspective and initiating action ${ }^{15}$. Active persons attributed greater importance to mastery, physical fitness, psychological state and appearance ${ }^{16}$. Azizi et al. ${ }^{17}$ reported that having a fit body, enjoyment and having fun, and improving physical and mental health were the main motivations for students. In another study the preferences, university students' confirmed for take part physical activities are fun, physical exercise and likeness of sports ${ }^{18}$. Hoon and Ho observed that educational experience have a direct impact on social activities ${ }^{19}$.

While looking at these reviews it was learned that no similar research studies has been published in participation motives of students towards physical activities in Saudi Arabia. Thus this study was taken up to identify and compare the participation motives of Saudi students towards physical activity and sports at different educational level and it was hypothesized that there would be no significant difference in participation motives among students' educational level.

\section{Method}

\subsection{Participants}

The participants $(\mathrm{N}=1039)$ were undergraduate students of KFUPM, Dhahran, Saudi Arabia who completed a 30 item survey assessing their participation motives of physical activity and sports. Their age was between 17 to 29 years; mean $20.60 \pm 1.679$. According to their educational level five categories were formed, namely, orientation ( $\mathrm{N}$ =352), freshmen $(\mathrm{N}=293)$, sophomore $(\mathrm{N}=191)$, junior $(\mathrm{N}=93)$, and senior $(\mathrm{N}=110)$. The dependent variables were participation motive factors, namely enjoyment/ interest, competence, appearance, fitness, and social.

\subsection{Instrument}

The questionnaire Motivation for Physical Activities Measure-Revised (MPAM-R) ${ }^{20}$ English version was administered to collect the data. The MPAM-R comprise of 30 items and their responses to each item were documented on a 7-point Likert scale ranging from 1 (not at all true) to 7 (very true). It comprises five participation motive factors, namely, enjoyment/interest motives (e.g., "I enjoy this activity"); competence/challenge motives (e.g., 'I want to obtain new skills'); appearance motives (e.g., 'I want to maintain weight to look better'); fitness/health motives (e.g., 'I want to maintain physical strength') and social motives (e.g., 'I want to be with my friends'). This instrument has established reliability for each factor with Cronbach's $\alpha$ ranging from .78 to .92. A demographic form was developed for this study to obtain information containing personal characteristics such as age, weight, height, educational level, number of hours involved in physical activity/sports per week etc.

\subsection{Collection of Data}

The data were collected through university e-mail services and some through distributing questionnaire directly to the students in the classrooms. Those who have done already through online were exempted from doing again. Participants were given adequate time to complete the questionnaire. A total of 1087 students participated in this survey in which 1039 questionnaires were valid.

\subsection{Data Analysis}

Statistical software SPSS version 17.0 was used to analyze the data. Data screening was undertaken to check the missing values and ensure that the values were within the expected range. Further Shapiro Wilk test was carried out to check the normality prior to data analyses. Descriptive statistics were calculated on the student's educational level (orientation, freshmen, sophomore, juniors and senior) on five motivating factors. Rank order was applied to find out the preferences of reasons for participation motives. Analysis of Variance (ANOVA) was employed to compare 
Table 1. Descriptive statistics of participation motive factors at different educational level

\begin{tabular}{|l|c|c|c|c|c|}
\hline \multirow{2}{*}{ Educational Level } & \multicolumn{5}{|c|}{ Participation Motives Factors } \\
\cline { 2 - 6 } & $\begin{array}{c}\text { Interest/Enjoyment } \\
\text { Mean } \pm \text { SD }\end{array}$ & $\begin{array}{c}\text { Competence } \\
\text { Mean } \pm \text { SD }\end{array}$ & $\begin{array}{c}\text { Appearance } \\
\text { Mean } \pm \text { SD }\end{array}$ & $\begin{array}{c}\text { Fitness } \\
\text { Mean } \pm \text { SD }\end{array}$ & $\begin{array}{c}\text { Social } \\
\text { Mean } \pm \text { SD }\end{array}$ \\
\hline Orientation (352) & $33.832 \pm 8.888$ & $32.613 \pm 9.01$ & $28.255 \pm 8.180$ & $25.911 \pm 6.582$ & $19.536 \pm 6.873$ \\
\hline Freshmen (293) & $32.539 \pm 9.724$ & $31.276 \pm 9.91$ & $27.658 \pm 8.874$ & $26.576 \pm 6.634$ & $16.651 \pm 7.086$ \\
\hline Sophomore (191) & $32.104 \pm 9.923$ & $30.397 \pm 9.14$ & $29.628 \pm 8.991$ & $26.832 \pm 6.671$ & $16.685 \pm 7.241$ \\
\hline Junior (93) & $32.849 \pm 9.647$ & $29.225 \pm 9.02$ & $29.957 \pm 9.036$ & $27.215 \pm 7.685$ & $15.946 \pm 7.747$ \\
\hline Senior (110) & $34.590 \pm 9.901$ & $32.845 \pm 9.62$ & $29.363 \pm 9.667$ & $27.845 \pm 6.614$ & $17.554 \pm 7.506$ \\
\hline Total (1039) & $33.142 \pm 9.563$ & $31.550 \pm 9.902$ & $28.609 \pm 8.892$ & $26.590 \pm 6.753$ & $17.667 \pm 7.270$ \\
\hline
\end{tabular}

the significance of difference among educational level and participation motivation factors. Further Tukey's posthoc comparison of means was applied to determine the significance of differences among motivational factors and educational levels. The criterion for statistical difference was set at .05 level of confidence.

\section{Results}

The collected data pertaining to this study has been analyzed using proper statistical tools and presented below.

Table 1 represents the descriptive statistics of participation motive factors as, senior students had higher mean on "interest or enjoyment" $(M=34.590)$, "competence" $(\mathrm{M}=32.845)$, and "fitness" $(\mathrm{M}=27.845)$ than other education level students. Whereas, junior and sophomore students had better scores on "appearance" factor ( $\mathrm{M}=$ 29.957 and 29.628) respectively than others. Orientation, students exhibited higher mean value $(M=19.356)$ on "social" factors than other levels of students.

Table 2 shows that reason for participation towards physical activity and sports stated by KFUPM students, on the basis of their percentage of responses. The five most important reasons for participation were 'because I want to be physically fit' (47\%), (fitness); 'because I want to look or maintain weight so I look better' (39\%), (appearance); 'because I want to improve my body shape'(39\%), (appearance); 'because I want to maintain my physical strength to live a healthy life' (38\%), (fitness); and 'because I want to maintain my physical health and well-being'(34\%), (fitness). Whereas, the least important reasons were 'because my friends want me to' (4\%), (social); 'because I want to meet new people' (8\%), (social); 'because I like to be with others who are interested in this activity' (9\%), (social); and 'because I want to be with my friends' (11\%), (social) which indicated the social factors.

In Table 3 the results of ANOVA revealed a highly significant difference among five categories of educational level on a 'competence' factor $F(4,1034)=3.419, p=.009$; and 'social' factor $F(4,1034)=9.7461, p=.001$. However, no significant difference was observed between 'fitness' factor $F(4,1034)=2.107, p=.078$; 'interest/enjoyment' factor $F(4,1034)=1.972, p=.097$ and 'appearance' factor $F(4,1034)=2.347, p=.053$.

When the F-ratio found significant, then Tukey's posthoc was applied to 'competence' and 'social' factors to determine the mean differences among the educational level (see Table 4). In 'competence' factor, the mean difference was observed between 'orientation' students and 'juniors' $(p=.030)$ and no difference was observed between other students. But 'social' factors showed a highly significant mean difference between 'orientation' 
Table 2. Rank order of participation motives expressed by KFUPM students

\begin{tabular}{|c|c|c|c|}
\hline Statement & Rank & No. of Respondents & $\%$ \\
\hline Because I want to be physically fit. & 1 & 488 & 47 \\
\hline Because I want to look or maintain weight so I look better. & 2 & 406 & 39 \\
\hline Because I want to improve my body shape. & 3 & 403 & 39 \\
\hline Because I want to maintain my physical strength to live a healthy life. & 4 & 391 & 38 \\
\hline Because I want to maintain my physical health and well-being & 5 & 354 & 34 \\
\hline Because I want to improve my appearance. & 6 & 324 & 31 \\
\hline Because I want to have more energy. & 7 & 319 & 31 \\
\hline Because it's fun. & 8 & 304 & 29 \\
\hline Because I want to define my muscles so I look better. & 9 & 304 & 29 \\
\hline Because it makes me happy. & 10 & 279 & 27 \\
\hline Because I enjoy this activity. & 11 & 277 & 27 \\
\hline Because I want to improve my cardiovascular fitness. & 12 & 275 & 26 \\
\hline Because I like to do this activity. & 13 & 271 & 26 \\
\hline Because I want to get better at my activity. & 14 & 256 & 25 \\
\hline Because I think it is interesting. & 15 & 240 & 23 \\
\hline Because I want to improve existing skills. & 16 & 205 & 20 \\
\hline Because I want to be attractive to others. & 17 & 189 & 18 \\
\hline Because I like the challenge. & 18 & 188 & 18 \\
\hline Because I want to obtain new skills. & 19 & 181 & 17 \\
\hline Because I enjoy spending time with others doing this activity. & 20 & 175 & 17 \\
\hline Because I want to keep-up my current skill level. & 21 & 170 & 16 \\
\hline Because I will feel physically unattractive if I don’t. & 22 & 157 & 15 \\
\hline Because I like activities which are physically challenging. & 23 & 152 & 15 \\
\hline Because I like engaging in activities which physically challenge me. & 24 & 151 & 15 \\
\hline Because I like the excitement of participation. & 25 & 132 & 13 \\
\hline Because I find this activity stimulating. & 26 & 119 & 11 \\
\hline Because I want to be with my friends. & 27 & 114 & 11 \\
\hline Because I like to be with others who are interested in this activity. & 28 & 93 & 9 \\
\hline Because I want to meet new people. & 29 & 85 & 8 \\
\hline Because my friends want me to. & 30 & 46 & 4 \\
\hline
\end{tabular}

and 'freshmen' ( $\mathrm{p}=.001)$, 'orientation' and 'sophomore' $(p$ $=.001)$ and 'orientation' and 'junior' $(p=.001)$.

\section{Discussion}

Descriptive data scores of student community exhibited higher mean scores on motivation factor 'interest/ enjoyment' followed by 'competence' factor. It reflects intrinsic motivation of students towards physical activity. This result is not surprising, enjoyment-interest motives refer to being physically energetic just because it makes people happy, enjoyable, interesting, stimulating, and it is fun. This result was supported with the previous studies: male students were frequently motivated by enjoyment ${ }^{21}$, 
Table 3. Significant difference of participation motives of students among educational level

\begin{tabular}{|c|c|c|c|c|c|c|}
\hline Participation Motive Factors & & Sum of Squares & df & Mean Square & $\mathrm{F}$ & $\mathrm{p}$ \\
\hline \multirow[t]{3}{*}{ Interest or enjoyment } & Between Groups & 718.620 & 4 & 179.655 & \multirow[t]{3}{*}{1.972} & \multirow[t]{3}{*}{.097} \\
\hline & Within Groups & 94216.299 & 1034 & 91.118 & & \\
\hline & Total & 94934.918 & 1038 & & & \\
\hline \multirow[t]{3}{*}{ Competence } & Between Groups & 1360.645 & 4 & 340.161 & \multirow[t]{3}{*}{3.419} & \multirow[t]{3}{*}{$.009^{*}$} \\
\hline & Within Groups & 102874.452 & 1034 & 99.492 & & \\
\hline & Total & 104235.097 & 1038 & & & \\
\hline \multirow[t]{3}{*}{ Appearance } & Between Groups & 738.603 & 4 & 184.651 & \multirow[t]{3}{*}{2.347} & \multirow[t]{3}{*}{.053} \\
\hline & Within Groups & 81336.749 & 1034 & 78.662 & & \\
\hline & Total & 82075.351 & 1038 & & & \\
\hline \multirow[t]{3}{*}{ Fitness } & Between Groups & 382.833 & 4 & 95.708 & \multirow[t]{3}{*}{2.107} & \multirow[t]{3}{*}{.078} \\
\hline & Within Groups & 46958.502 & 1034 & 45.414 & & \\
\hline & Total & 47341.336 & 1038 & & & \\
\hline \multirow[t]{3}{*}{ Social } & Between Groups & 1993.376 & 4 & 498.344 & \multirow[t]{3}{*}{9.746} & \multirow[t]{3}{*}{$.001^{*}$} \\
\hline & Within Groups & 52869.067 & 1034 & 51.131 & & \\
\hline & Total & 54862.443 & 1038 & & & \\
\hline
\end{tabular}

achievement is fundamental for enjoyment ${ }^{6,7}$, enjoyment, having fun, and experiencing joy as major motives for participation and practicing sports ${ }^{22,23}$.

The results revealed that fitness factor has improved progressively with education levels. The findings are consistent with previous results, students with a higher level of studies exhibited high percentage of students motivated towards health and fitness ${ }^{24-26}$.

The most important reason identified for participation towards physical activity as 'fitness and appearance' factor; having good physical fitness, maintaining physical strength to live a healthy life, improve body shape and maintain weight to look better. These results are confirming the findings reliably attained from earlier research studies ${ }^{17,27-29}$. Physical health acknowledged as a significant motive ${ }^{30}$ and fitness reflects health benefits $^{31}$. Conferring to Self-Determination Theory ${ }^{32}$ fitness motives reflect the relatively autonomous form of motivation represented in 'identified regulation' (personally held values), whereas appearance-based motives are extrinsic in nature, tending to reflect 'introjected regulation' (for avoiding external sources of disapproval). It appears that students pursue physical activities and sports, mainly because of their external motivation.

Whereas, the least important reason for participation towards physical activity and sports were social factors; that 'being with friends' and 'meeting new people'. These findings are consistent with previous studies ${ }^{33-35}$.
Spending leisure time, being with friends, and participating in competitions was found as the lowest motivational dimensions ${ }^{36}$.

To impart the knowledge of fitness and health benefits, the mentors and counselors should help and motivate these students to take up the physical activities seriously. Then physical education teachers and coaches should emphasize positive sensation such as fun and excitement that results from participation while lowering their emphasis on peer comparisons and competition.

Results of the study revealed that students joined the undergraduate program orientation (preparatory year) with vigor and high level of competence to face challenges, but may be due to the competitive study environment of the university competence level has gradually decreased and students took time to cope with the system of teaching and learning. Competence level has reached its peak during senior level, which definitely prepares them to compete and face challenges of life.

Sport is a social medium through which virtually every community and culture around the globe come together ${ }^{37}$. Results showed that 'social' factor had a significant difference among students' social motives. Being a residential university, there is less social interaction with people outside the campus; students are new to this campus and come from different regions of the country with different socioeconomic background. The climatic conditions of Saudi Arabia are very hot, so outdoor sports 
Table 4. Multiple comparisons of mean difference by using Tukey's HSD

\begin{tabular}{|c|c|c|c|c|}
\hline Dependent Variable & $\begin{array}{l}\text { Educational Level } \\
\text { (I) }\end{array}$ & $\begin{array}{c}\text { Educational Level } \\
(\mathrm{J})\end{array}$ & $\begin{array}{c}\text { Mean Difference } \\
(\mathrm{I}-\mathrm{J})\end{array}$ & $p$ \\
\hline \multirow{20}{*}{ Competence } & \multirow{4}{*}{$\begin{array}{l}\text { Orientation } \\
32.613\end{array}$} & Freshmen (31.276) & 1.337 & .437 \\
\hline & & Sophomore (30.397) & 2.216 & .098 \\
\hline & & Junior (29.225) & $3.388^{*}$ & $.030^{*}$ \\
\hline & & Senior (32.845) & -.232 & 1.00 \\
\hline & \multirow{4}{*}{$\begin{array}{l}\text { Freshmen } \\
31.276\end{array}$} & Orientation (32.613) & -1.337 & .437 \\
\hline & & Sophomore (30.397) & .879 & .878 \\
\hline & & Junior (29.225) & 2.051 & .418 \\
\hline & & Senior (32.845) & -1.569 & .623 \\
\hline & \multirow{4}{*}{$\begin{array}{l}\text { Sophomore } \\
30.397\end{array}$} & Orientation (32.613) & -2.216 & .098 \\
\hline & & Freshmen (31.276) & -.879 & .878 \\
\hline & & Junior (29.225) & 1.172 & .886 \\
\hline & & Senior (32.845) & -2.448 & .243 \\
\hline & \multirow{4}{*}{$\begin{array}{l}\text { Junior } \\
29.225\end{array}$} & Orientation(32.613) & $-3.388^{*}$ & $.030^{*}$ \\
\hline & & Freshmen (31.276) & -2.051 & .418 \\
\hline & & Sophomore (30.397) & -1.172 & .886 \\
\hline & & Senior (32.845) & -3.620 & .076 \\
\hline & \multirow{4}{*}{$\begin{array}{l}\text { Senior } \\
32.845\end{array}$} & Orientation (32.613) & .232 & 1.000 \\
\hline & & Freshmen (31.276) & 1.569 & .623 \\
\hline & & Sophomore (30.397) & 2.448 & .243 \\
\hline & & Junior (29.225) & 3.620 & .076 \\
\hline \multirow{20}{*}{ Social } & \multirow{4}{*}{$\begin{array}{l}\text { Orientation } \\
19.536\end{array}$} & Freshmen (16.651) & $2.885^{*}$ & $.001^{*}$ \\
\hline & & Sophomore (16.685) & $2.851^{*}$ & $.001^{*}$ \\
\hline & & Junior (15.946) & $3.590^{*}$ & $.001^{*}$ \\
\hline & & Senior (17.554) & 1.982 & .083 \\
\hline & \multirow{4}{*}{$\begin{array}{c}\text { Freshmen } \\
16.651\end{array}$} & Orientation (19.536) & $-2.885^{*}$ & .000 \\
\hline & & Sophomore (16.685) & -.033 & 1.00 \\
\hline & & Junior (15.946) & .705 & .922 \\
\hline & & Senior (17.554) & -.902 & .791 \\
\hline & \multirow{4}{*}{$\begin{array}{l}\text { Sophomore } \\
16.685\end{array}$} & Orientation (19.685) & $-2.851^{*}$ & $.001^{*}$ \\
\hline & & Freshmen (16.651) & .033 & 1.00 \\
\hline & & Junior (15.946) & .733 & .925 \\
\hline & & Senior (17.554) & -.868 & .849 \\
\hline & \multirow{4}{*}{$\begin{array}{l}\text { Junior } \\
15.946\end{array}$} & Orientation (19.685) & $-3.590^{*}$ & $.001^{*}$ \\
\hline & & Freshmen (16.651) & -.705 & .922 \\
\hline & & Sophomore (16.685) & -.739 & .925 \\
\hline & & Senior (17.554) & -1.608 & .500 \\
\hline & \multirow{4}{*}{$\begin{array}{l}\text { Senior } \\
17.554\end{array}$} & Orientation (19.685) & -1.982 & .083 \\
\hline & & Freshmen (16.651) & .902 & .791 \\
\hline & & Sophomore (16.685) & .868 & .849 \\
\hline & & Junior (15.946) & 1.608 & .500 \\
\hline
\end{tabular}


activities are very much restricted. Another reason might be most of the students come from large families and feel less need to socialize outside their families. A significant difference found between competence and social factors among students at different educational levels. Thus the hypothesis set was partially rejected.

The previous findings reported that the choices of friendship as the foremost motive to take part in physical activities ${ }^{38}$, men are more motivated by social experience $^{39}$. The findings are contrary to our result, as the university students are always busy with their home works, presentations, projects and study programs so there might be very less time for doing physical activities and sports as a team or socializing with others. Whereas, senior students have study tours, project works to be submitted as a team, which improved their interactions with others, and this translated to their urge to indulge in physical activity and sports programs along with motives to improve their fitness, appearance, competence level, interest and socialization.

Rewards or incentives may be given to the students for sports participation which will be an external motivation to students to engage in physical activities. In order to optimize the social experience of students there is a need for strategies to reduce the gap in socialization among students.

\section{Conclusion}

University students' rated the most important reasons for participation towards physical activity and sports as fitness and then appearance factors, which are explained by extrinsic motivation. Students tend to improve their competence, enjoyment or interest through physical activity and sports to optimize their physical well-being with progression of educational levels. The university has sufficient infrastructural facilities for physical activity and sports but students are not optimizing it to their advantage. The least important reason for participation motives for all level of students were social factors.

The results of the present study should be interpreted in view of some limitations. The current findings call attention to possible motivational factors for participation motives of University students towards physical activity and sports. Qualitative research methods could also be used to fully understand how the participants understood the meaning of the word "physical activity". Future research may be explored cognitive outcomes in addition to motivational outcomes for example attentional span, concentration and level of learning.

\section{Acknowledgement}

This research was supported by Deanship of Scientific Research, King Fahd University of Petroleum and Minerals, Dhahran, Saudi Arabia under Grant No. IN111022.

\section{References}

1. Bosnar K, Balent B. Introduction to psychology of sports: Manual for sports coaches; 2009.

2. Omorou YA, Erpelding ML, Ascalon H, Vuillemin A. Contribution of taking part in sport to the association between physical activity and quality of life. Quality of Life Research. 2013; 8(22):2021-9.

3. Stevenson A. Oxford dictionary of English. 3rd ed. Oxford University Press; 2010.

4. Weinberg RS, Gould D. Foundations of sport and exercise psychology. 3rd ed. Champaign, IL: Human Kinetics; 2003.

5. Weiss MR, Petlickhoff LM. Children's motivation for participation in and withdrawal from sport: Identifying the missing link. Pediatric Exercise Science. 1989; 1(3):195-211.

6. Cervello EM, Escarti A, Guzman JF. Youth sport dropout from the achievement goal theory. Psicothema. 2007; 19(1):65-71.

7. Whitehead J, Andree K, Lee ML. Achievement perspectives and perceived ability: How far do interactions generalize in youth sport? Psychology of Sport and Exercise. 2004; 5(3):291-317.

8. Warburton DER, Nicol CW, Bredin SSD. Prescribing exercise as preventive therapy. CMAJ. 2006; 174(7):961-74. DOI: $10.1503 /$ cmaj.1040750.

9. Knapen J, Vancampfort D, Schoubus B, Probst M, Sienaert P, Pieters G. Exercise for the treatment of depression. The Open Complementary Medicine Journal. 2009; 1:78-83. DOI: 10.2174/1876391X00901010078.

10. Sports and Health: Preventing and managing non-communicable disease-right to play international. Report of UN sport for development and peace; 2010. p. 34-42.

11. Goudas M, Hassandra M. Greek students' motives for participation in physical education. Int J Phys Educ. 2006; 43(2):85-9.

12. Fang J. Research on motivation, attribution, self-efficacy and sport learning effects. Journal of Beijing Sport University. 2007; 30(12):1691-2.

13. Standage M, Gillison F. Students' motivational responses toward school physical education and their relationship to general self-esteem and health-related quality of life. Psychology of Sport and Exercise. 2007; 8(5):704-21. 
14. Strel J, Sila B. Sport activity of Slovenian adolescents aged between 15 and 18. Sport. 2010; 58:124-9.

15. Roberts GC. Motivation in sport and exercise: Conceptual constraints and convergence. In: Roberts GC, editors. Motivation in sport and exercise. Champaign, IL: Human Kinetics; 1992. p. 3-29.

16. Aaltonen S, Rottensteiner M, Kaprio J, Kujala UM. Motives for physical activity among active and inactive persons in their mid-30s. Scand J Med Sci Sports. 2014; 24:727-35.

17. Azizi B, Farahani MJ, Khabiri M. Survey of the attitudes of students living in university of Tehran dormitories towards sport for all. Sport Management. 2011; 2(8):75-91.

18. Garcia M. Spaniards and sport: Practice and behavior in the last decade of the 20th century. A survey of sports habits in the Spanish population, 2000. 1 ed. Madrid, Espana: CSD y MECD; 2001.

19. Hoon KY, Ho YC. The impact of marine sports experience on life satisfaction. Indian Journal of Science and Technology. 2015; 8(18):75.

20. Ryan RM, Frederick CM, Lepes D, Rubio N, Sheldon KM. Intrinsic motivation and exercise adherence. International Journal of Sport Psychology. 1997; 28(4):335-54.

21. Egli T, Bland HW, Melton BF, Czech DR. Influence of age, sex and race on college students' exercise motivation of physical activity. Journal of American College Health. 2011; 59(5):399-406. DOI: 10.1080/07448481.2010.513074.

22. Waldron JJ, Dieser RB. Perspectives of fitness and health in college men and women. J Coll Student Dev. 2010; 51(1):65-78.

23. Safania AM. Study on the leisure time of Islamic Azad University female students and the role of sports in spending such time. Harakat. 2001; 9:127-40.

24. Juan FR, Rodriguez AIH. El interes por la practica de actividad fisico-deportiva de tiempo libre del alumnado de la Universidad de Almeria. Un estudio longitudinal. apunts Educacion Fisica y Deportes. 2001; 63(86):92.

25. Masachs JM. Evolution of the reasons for participating in exercise programs. Revista de Psicologia del Deporte. 1994; 3(1): 71-7.

26. Sanchez-Barrera M, Perez M, Godoy J. Physical activity patterns in a Spanish simple. Revista de Psicologia del Deporte.1995; 7(8):51-71.
27. Kamarudin K, Fauzee M. Attitudes toward physical activities among college students. Journal of Psychological Research. 2007; 22(1-2):43-54.

28. Furjan-Mandic G, Kondric M, Tusak M, Rausavljevic N, Kondric L. Sports students' motivation for participating in table tennis at the faculty of kinesiology in Zagreb. Editorial Board; 2010. p. 44-7.

29. Ramezaninejad R, Rahmaninia F, Taghavi SA. Study of socioeconomic status and motives of participants in sport for all. Sport Management. 2010; 1(2):5-19.

30. Stefanek KA. An exploration of participation motives among collegiate taekwondo participants. Kinesiology Publications: University of Oregon; 2004.

31. Zaggelidis G, Martinidis K, Zaggelidis S. Comparative study of factors - motives in beginning practicing judo and karate. Physical Training: Fitness for Combatives; 2004. Available from: http://ejmas.com/pt/2004pt/ptart_zaggelidis_0504.html

32. Deci EL, Ryan RM. Intrinsic motivation and self-determination in human behavior. New York: Plenum; 1985.

33. Heesch KC, Brown DR, Blanton CJ. Perceived barriers to exercise and stage of exercise adoption in older women of different racial/ethnic groups. Women and Health. 2000; 30(4):61-76. DOI: 10.1300/J013v30n04_05.

34. Wilson PM, Rodgers WM, Fraser SN. Cross-validation of the revised motivation for Physical Activity Measure in active women. Research Quarterly for Exercise and Sport. 2002; 73(4):471-7.

35. Gill DL, Gross JB, Huddleston S. Participation motivation in youth sports. Int J Sport Psychol. 1983; 14(1):1-14.

36. Mirsafian H, Mohamadinejad A, Homaei R, Hedi C. Motivations of Iranian University students for participation in sporting activities. Phys Cult Sport Stud Res. 2013; 59(1):42-8. DOI: 10.2478/pcssr-2013-0016.

37. Eitzen SD, Sage GH. Sociology of North American sport. New York: McGraw-Hill; 2003.

38. Ryckman RM, Hamel J. Female adolescents' motives related to involvement in organized team sports. Int J Sport Psychol. 1992; 23(2):147-260.

39. Bastos AA, Salguero A, Gonzalez-Boto R, Marquez S. Motives for participation in physical activity by Brazilian adults. Perceptual and Motor Skills. 2006; 102(2):358-67. 